\title{
DETERMINANTS OF FISCAL STRESS \\ IN CENTRAL SULAWESI 2014-2018 PERIOD
}

\section{DETERMINANTS OF FISCAL STRESS IN CENTRAL SULAWESI 2014-2018 PERIOD}

\author{
Zakina Zein Al-Hadar1), Mohamad Ichwan²), Santi Yunus ${ }^{3)}$ \\ ${ }^{1,2,3}$ Faculty of Economic and Business, Universitas Tadulako, Indonesia
}

\begin{abstract}
This study aims to analyze the effect the Local-owned Source Revenue, Regional Expenditure and Gross Regional Domestic Product on Fiscal Stress in Regencies/Cities of Central Sulawesi Province Period 2014 - 2018. Data analysis was using panel data regression method. The results of this study indicated that simultaneously variable Local-owned Source Revenue (PAD), Regional Expenditure (BD), and Gross Regional Domestic Product (PDRB) had a significant effect on Fiscal Stress in Regencies/Cities of Central Sulawesi Province for 2014 - 2018 period. Partially, Local-owned Source Revenue variable (PAD) had reduced and significantly decreased Fiscal Stress in the Regency/Cities of Central Sulawesi Province period 2014-2018. Regional expenditure variable (BD) had increase and significantly affected Fiscal Stress in Regencies/ Cities of Central Sulawesi Province Period 2014 - 2018. While Gross Regional Domestic Product (PDRB) variable had increase and was insignificant to Fiscal Stress in Regencies/Cities of Central Sulawesi Province 2014 - 2018 period.
\end{abstract}

Keywords: Fiscal Stress, Local-owned Source Revenue, Regional Expenditure and Gross Regional Domestic Product

\section{INTRODUCTION}

The Government started implementing regional autonomy in 2001, then the paradigm shifted from centralization to decentralization. Decentralization is the transfer of government power by the Central Government to autonomous regions within the system of the Unitary State of the Republic of Indonesia. The main foundation in the implementation of regional autonomy is Law number 32 of 2004 which was later changed to Law number 9 of 2015 concerning Regional Government and Law number 25 of 1999, which was enhanced by Law number 33 of 2004 concerning Financial Balance between Central Government and Local Government (Septira dan Prawira, 2019). Government Regulation number 2 of 2018 concerning Minimum Service Standards explains that the granting of the widest possible autonomy to regions is directed at accelerating the realization society's welfare or people's welfare through improving service, empowerment, and the role of society as well as the regions expected to be able to increase regional competitiveness, potential and diversity in the principle of the Unitary State of The Republic of Indonesia.

Regional autonomy policies and fiscal decentralization requires regions to be able to optimize various potential or fiscal capacities, with the aim of reducing the level of dependency on the Central Government. Each region has a different fiscal capacity. Regions with high fiscal capacity are lucky because they have potential

\footnotetext{
*Corresponding author. Email address: mitandju@yahoo.com
} 


\section{AFEBI Economic and Finance Review (AEFR) \\ Volume 5, No 02 (2020)}

sources of revenue originating from regional taxes, regional levies, as well as the availability of sufficient natural resources, which can be used as sources of regional revenues. Unlike the case of regions with low fiscal capacity, autonomy can cause its own problem due to demands to increase regional independence. When compared to the situation before autonomy, such regions will have higher fiscal stress.

Fiscal stress or budgetary/fiscal pressure is one of the problems which can hinder the development process of a region. The cause of Fiscal Stress is from the limited budget receipts to finance the implementation of development and increase regional independence. High Fiscal stress will affect to the government's financial performance in managing and allocating the budget. It will encourage local government to make various breakthroughs to meet the financing to carry out government functions and public services, including revision in budget implementation (Junita dan Abdullah, 2016). One of the causes of budget changes is income uncertainty (Forrester, 2002). Revenue forecast have an important role in the budgeting process. Regional financial conditions can become unstable because realized revenue is not sufficient to finance planned expenditures. If there is a discrepancy between the projection and realization of revenue, the government must revise the prepared budget for balance (Cornia, 2004). One of the government response to compensate the budget deficit is to cut the expenditure (Reschovsky, 2003).

Empirically and theoretically, Fiscal Stress formed by the difference and the patterns of regional revenue and regional expenditure. The regional revenue and regional expenditure show the real situation of local government. If local government is in the situation with the high-level dependency, that is derived from regional tax, regional retribution, and available natural resources, then the flexibility in policy direction and development can be achieved. The direction of policy and development is reflected in spending structure, especially direct expenditure (direct personnel expenditure, goods and services expenditure and capital expenditure) which reflects in government policy in achieving public service goals (Manafe et al., 2018). Each region has its own income and spending structure. Some local governments tend to adopt consumption-based taxation, meanwhile the other regions adopt income-based taxation. Each situation has a different impact and is influenced by Fiscal Stress (Shamsub and Akoto, 2004). Regardless of those differences, in Indonesia, it can be concluded that Fiscal Stress affects to the structure of Regional Government Budget (Setiyawan and Adi, 2006).

The income used by the regions to finance regional development is sourced from local-owned source Revenue (PAD), transfer funds and other legitimate regional revenues. The decline of economic activity in various regions can also has impact on decreasing local-owned source Revenue, so that these areas will depend on transfer fund which can cause the Fiscal Stress symptoms. Local-owned source Revenue based on Law number 33 of 2004 concerning the Financial Balance between the Central Government and the Regional Government, is the income obtained by the regions collected based on regional regulation in accordance with the law and regulations. Local-owned source Revenue includes to regional tax, regional retribution, separated regional wealth management and the other official regional incomes.

Fiscal Stress (budgetary pressure) is not only affected by local-owned source revenue, but it is also influenced by the structure/pattern of regional expenditure. The changes structure of regional expenditure especially in increasing development spending is to increase Regional Income. The Regional expenditure budget always increases every year in line with the economic growth in the area. Each region 
implements autonomy is required to be able to increase regional income by developing new potential income so that the fund to finance Regional Spending remains available. If the regional income is not sufficient to finance Regional Spending, so it will have an impact on the occurrence the Fiscal Stress, because the changes of financing will have more caused by increasing of public services demand (Septira and Prawira, 2019). Fiscal Stress triggered by budget deficit namely the spending was much more than revenue (Reschovsku, 2003).

Budget deficit is the difference between the amount received and the amount spent. Regional income side is used by local ownes-source revenue, because local owned-source revenue is not only a source of regional revenue, but also as an indicator of regional independence. The higher local owned-source revenue, the less dependent the regions are on transfer fund from Central Government. If the Central Government meets a budget shock, it can be said that it will not have a big impact to regional budget. Spending side in region is used to regional expenditure. The amount of regional expenditure shows how much the region has budgeted its fund to develop the region. The higher regional budget gap, the higher Fiscal Stress.

Table 1.1 The following presents an overview of the average financial condition of the Regional Government in the District / city of Central Sulawesi Province which shows symptoms of Fiscal Stress in 2014-2018.

Table 1

Average Financial Condition of Local Government in District /City of Sulawesi Tengah Province Year 2014-2018 (Billion Rupiah)

\begin{tabular}{|c|c|c|c|c|c|c|}
\hline Regency/City & PAD & $\begin{array}{c}\text { Total } \\
\text { Transfer }\end{array}$ & $\mathrm{BD}$ & $\begin{array}{l}\text { PAD + } \\
\text { Transfer }\end{array}$ & $\begin{array}{c}\text { PAD } \\
\% \\
\end{array}$ & $\begin{array}{l}\text { Transfer/ } \\
\text { BD }(\%)\end{array}$ \\
\hline $\begin{array}{l}\text { Banggai } \\
\text { Kepulauan }\end{array}$ & 24 & 548 & 745 & 572 & 4,17 & 73,55 \\
\hline Banggai & 96 & 922 & 1.669 & 1.018 & 9,53 & 57,45 \\
\hline Morowali & 108 & 663 & 858 & 772 & 12,92 & 78,24 \\
\hline Poso & 82 & 946 & 1.212 & 1.029 & 8,03 & 77,86 \\
\hline Donggala & 63 & 860 & 1.123 & 923 & 6,88 & 76,48 \\
\hline Tolitoli & 71 & 753 & 918 & 824 & 8,51 & 81,98 \\
\hline Buol & 56 & 685 & 928 & 742 & 7,49 & 74,77 \\
\hline $\begin{array}{l}\text { Paringi } \\
\text { Moutong }\end{array}$ & 115 & 970 & 1.252 & 1.086 & 10,47 & 79,04 \\
\hline $\begin{array}{l}\text { Tojo Una- } \\
\text { una }\end{array}$ & 55 & 748 & 987 & 803 & 6,94 & 75,90 \\
\hline Sigi & 42 & 828 & 939 & 870 & 4,73 & 93,10 \\
\hline $\begin{array}{l}\text { Banggai } \\
\text { Laut }\end{array}$ & 18 & 412 & 571 & 430 & 4,01 & 75,20 \\
\hline $\begin{array}{l}\text { Morowali } \\
\text { Utara }\end{array}$ & 42 & 650 & 817 & 692 & 6,31 & 79,70 \\
\hline Kota Palu & 217 & 884 & 1.284 & 1.101 & 23,14 & 68,87 \\
\hline $\begin{array}{l}\text { Sulawesi } \\
\text { Tengah }\end{array}$ & 993 & 9.874 & 13.31 & 10.868 & 9,53 & 73,95 \\
\hline
\end{tabular}

Table 1 shows from 2014-2018, the average of local revenue in district/province of Central Sulawesi Province to regional revenue is relatively small, 


\section{AFEBI Economic and Finance Review (AEFR) \\ Volume 5, No 02 (2020)}

which is less than 25 percent $(4,01$ percent to 23,14 percent), while transfer funds contributes greatly to the dominance in regional spending, namely 57,45 percent to 93,10 percent. Regarding to regional spending will continuously increase from year to year to encourage the implementation of development in each region, this dominance will have bad impact in long term. If this condition is not followed by increasing local own-source revenue, so the dependence on transfer funds from Central Government will trigger the fiscal stress phenomenon.

Gross Regional Domestic Product (PDRB) describes the ability of regions to manage their natural resources. The amount of PDRB generated by each region depends on the potential of natural resource and production factors in the area. These limited supply of production factors causes the difference of the GRDP in each region (Muda, 2012). PDRB is a potential source of regional revenue. The ability of the society to pay taxes and retributions to the region depends is very dependent on the economic activities carried out by the society. The more economic activities the society carried out, the higher the income earned by the society and regional efforts to increase regional income through local taxes and retributions can increase.

The high Gross Regional Domestic Product (PDRB) means that the region will be able to meet the needs of the region itself and have sufficient economic capacity to be deposited with the Regional Government in the form of taxes and retribution. If taxes and retributions obtained from the society are high, the Fiscal Stress in the region will be reduced. The increase in regional of GRDP can also be caused by sustainable local own-source revenue growth. If local own-source revenue increases, the funds owned by the Regional Government will be higher and the level of regional independence will also increase, so that the Regional Government will be more active in exploring region potency, increasing GRDP and reducing the Fiscal Stress.

Regions will be able to finance the regional development through their regional income. If the regional GRDP is not increased, the efforts to increase local ownsource revenue will be meaningless (Muda, 2012).

The Gross Regional Domestic Product (PDRB) in Central Sulawesi Province in 2014-2018 has increased, which was in 2014 by 90.246 billion rupiahs to 150,032 billion rupiahs in 2018. This trend of increasing PDRB illustrates the good economic activity in Central Sulawesi Province during within 5-year period. This good economic development is expected to be able to increase the revenue side of the region, especially in terms of regional taxes and regional retribution which will reduce the number of Fiscal Stress.

\section{RESEARCH METHOD}

\section{A. Type of Research}

This research uses associative research type, specifically associative research type which aims to determine the relationship between two variables (Sugiyono, 2017). This study uses the associative type to determine the relationship between the variables of local-own resource Revenue (PAD), Regional Expenditures (BD) and Gross Regional Domestic Product (PDRB) on Fiscal Stress. The types of data are divided into two, they are qualitative data and quantitative data (Sugiyono, 2017). The type of data used in this study is quantitative data, which is data in the form of numbers. The data used in this study are:

1. Local-owned resource revenue (PAD) in district / Province of Central Sulawesi Period 2014-2018; 
2. Regional expenditure (BD) in district / Province of Central Sulawesi Period 20142018;

3. Gross Regional Domestic Product (GRDP) in district / Province of Central Sulawesi Period 2014-2018.

\section{B. Data Collection Method}

The data used in this research was obtained by a literature study at Central Bureau Statistics in Province of Central Sulawesi and they will be processed according to the needs of this research.

\section{Data Analysis}

The method used in this study is data panel (Pooled Data). Data panel is a set data contains of individual sample data (households, companies, districts/cities, and others) in a certain time period. Panel data is a combination of cross-section and time series observations (Ekananda, 2016). According to Widarjono (2009) the estimation of the regression model combining all data has the form of a general specification, following :

$\mathbf{Y}=\beta_{0}+\beta_{1} \mathbf{X}_{1}+\beta_{2} \mathbf{X}_{2}+\ldots+\beta_{\mathbf{n}} \mathbf{X}_{\mathbf{n}}+\mu_{\mathrm{it}}$

And it is formulated in this study to become:

$\mathbf{F S}=\beta_{0}+\beta_{1} \mathbf{P A D}+\beta_{2} \mathbf{B D}+\beta_{3}$ PDRB $+\mu_{\mathrm{it}}$

Then it is transformed as below:

LnFS $=\beta_{0}+\beta_{1} \operatorname{LnPAD}+\beta_{2} \operatorname{LnBD}+\beta_{3} \operatorname{Ln}$ PDRB $+\mu_{\mathrm{it}}$

Formula information:

$\begin{array}{ll}\mathrm{FS} & =\text { Fiscal Stress } \\ \mathrm{PAD} & =\text { Local-owned resource revenue } \\ \mathrm{BD} & =\text { Regional expenditure } \\ \mathrm{PDRB} & =\text { Gross Regional Domestic Product } \\ \beta_{0} & =\text { Intercept } \\ \beta_{1}, \beta_{2}, \beta_{3} & =\text { Regression coefficient } \\ \mu & =\text { error term } \\ \mathrm{i} & =\text { Cross Section } \\ \mathrm{t} & =\text { Time Series }\end{array}$

\section{RESULT AND DISCUSSION}

The results of the Chow test and Hausman test choosed the fixed effect model and the random effect model, so that to determine the best model used in the current panel data method, it is necessary to continue with the LM test between the common effect model and the random effect model according to the initial hypothesis of the LM test, by using the residuals from the simple effects method, the Breuch Pagan probability value is 0.0003 which is smaller than the value, it is 0.05 . Based on this, it can be seen that $\mathrm{LM}<$ critical value, so it can be concluded that the random effect model is better than the common effect model.

\section{A. Random Effect Model}

Based on the results of panel data regression analysis using E-views 10, the overall random effect model equation which covers 13 districts/cities in Central Sulawesi Province is obtained as follows:

$$
\begin{aligned}
\text { FS }= & \beta_{0}-\beta_{1} \text { PAD }+\beta_{2} \text { BD }+\beta_{3} \text { PDRB }+\mu_{\mathrm{it}} \\
& -\mathbf{0 . 6 7 6 1 4 6}-0.077752 \text { PAD }+1.088875 \text { BD }+0.006991 \text { PDRB }+\mu_{\mathrm{it}}
\end{aligned}
$$




$$
(-2.167502) * *(-6.715044) * * *(53.09303) * * * 0.469071)
$$

The probability value that is in the number $<1$ percent is symbolized by three stars $(* * *)$, the probability value that is in the number between 1 to 5 percent is symbolized by two stars $(* *)$ and the probability value that is in the number more than 10 percent is not symbolized using a star.

The results of the random effect model as a whole show that if the Localowned source Revenue (PAD), Regional Expenditure (BD) and Gross Regional Domestic Product (PDRB) variables are considered constant, the Fiscal Stress variable will decrease by 0.676146 percent. This equation also describes the relationship between PAD, BD and PDRB variables with the Fiscal Stress variable. The Local-own source Revenue (PAD) variable will cause a decrease in Fiscal Stress by 0.077752 percent with the assumption that other variables are considered constant, meaning that if PAD has decreased by 1 percent, Fiscal Stress has increased by 0.077752 percent. The Regional expenditure (BD) variable has an increasing impact on Fiscal Stress by 1.088875 percent with the assumption that other variables are considered constant, meaning that if Regional Expenditure (BD) has increased by 1 percent, Fiscal Stress has increased by 1.088875 percent. Gross Regional Domestic Product (PDRB) causes an increase of 0.006991 percent in Fiscal Stress with the assumption that other variables are considered constant, meaning that if Gross Regional Domestic Product (PDRB) has increased by 1 percent, Fiscal Stress has increased by 0.006991 percent.

The equations of each cross section random effect model in 13 districts / cities in Central Sulawesi Province are as follows:

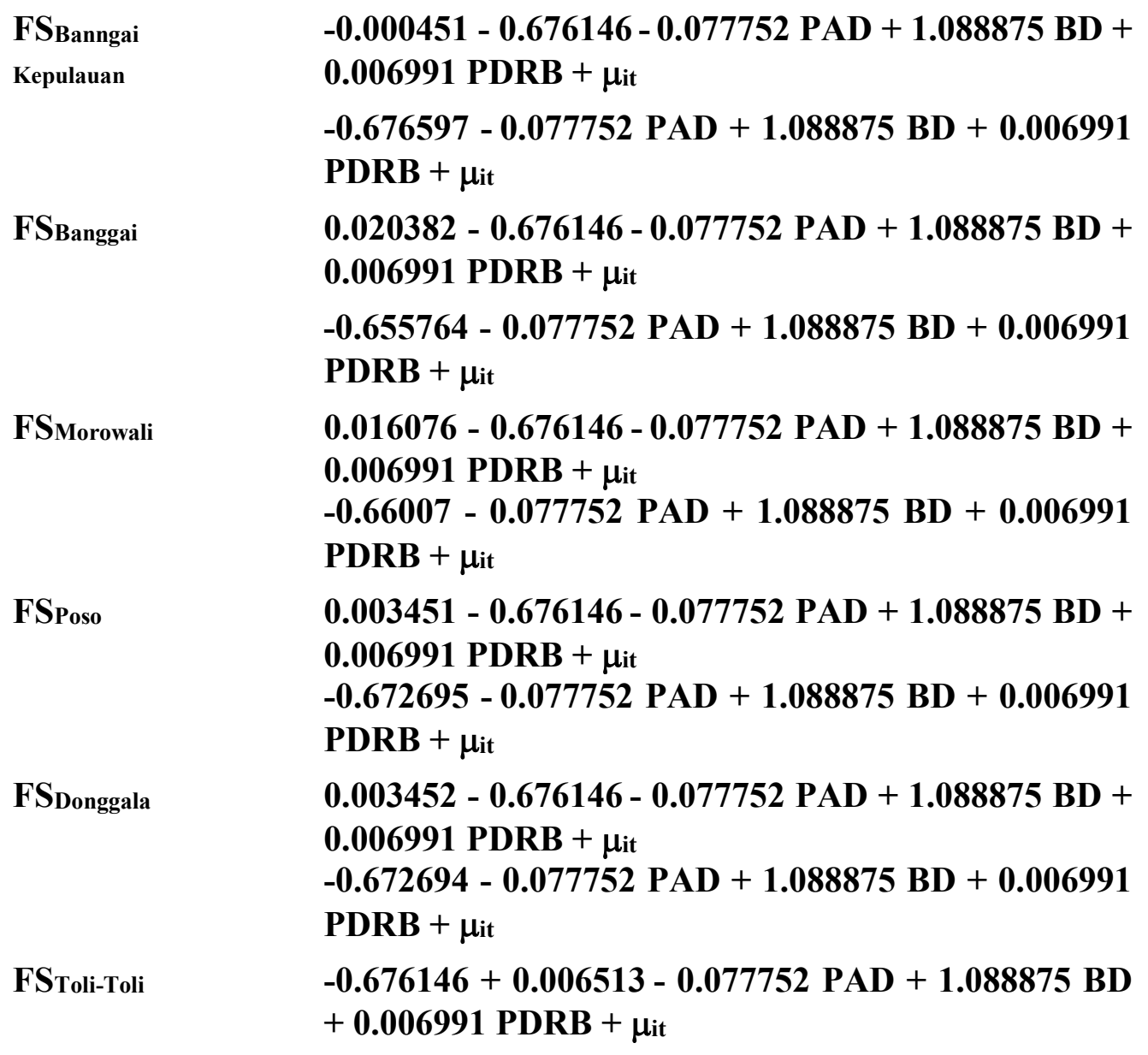




$$
\begin{aligned}
& -0.669633-0.077752 \text { PAD }+1.088875 \text { BD }+0.006991 \\
& \text { PDRB }+\mu_{\text {it }}
\end{aligned}
$$

\begin{tabular}{|c|c|}
\hline FS $_{\text {Buol }}$ & $\begin{array}{l}0.007868-0.676146-0.077752 \text { PAD }+1.088875 \text { BD }+ \\
0.006991 \text { PDRB }+\mu_{\text {it }} \\
-0.668278-0.077752 \text { PAD }+1.088875 \text { BD }+0.006991 \\
\text { PDRB }+\mu_{\text {it }}\end{array}$ \\
\hline $\begin{array}{l}\text { FSParigi } \\
\text { Moutong }\end{array}$ & $\begin{array}{l}-0.004769-0.676146-0.077752 \text { PAD }+1.088875 \text { BD }+ \\
0.006991 \text { PDRB }+\mu_{\text {it }} \\
-0.680915-0.077752 \text { PAD }+1.088875 \text { BD }+0.006991 \\
\text { PDRB }+\mu_{\text {it }}\end{array}$ \\
\hline $\begin{array}{l}\text { FS Tojo Una- } \\
\text { Una }\end{array}$ & $\begin{array}{l}0.013068-0.676146-0.077752 \text { PAD }+1.088875 \text { BD }+ \\
0.006991 \text { PDRB }+\mu_{\text {it }} \\
-0.663078-0.077752 \text { PAD }+1.088875 \text { BD }+0.006991 \\
\text { PDRB }+\mu_{\text {it }}\end{array}$ \\
\hline FSSigi & $\begin{array}{l}-0.008850-0.676146-0.077752 \text { PAD }+1.088875 \text { BD }+ \\
0.006991 \text { PDRB }+\mu_{\text {it }} \\
-0.684996-0.077752 \text { PAD }+1.088875 \text { BD }+0.006991 \\
\text { PDRB }+\mu_{\text {it }}\end{array}$ \\
\hline $\begin{array}{l}\text { FS Banngai } \\
\text { Laut }\end{array}$ & $\begin{array}{l}\text { 0.004550 }-0.676146-0.077752 \text { PAD }+1.088875 \text { BD }+ \\
0.006991 \text { PDRB }+\mu_{\text {it }} \\
-0.671596-0.077752 \text { PAD }+1.088875 \text { BD }+0.006991 \\
\text { PDRB }+\mu_{\text {it }}\end{array}$ \\
\hline $\begin{array}{l}\text { FSMorowali } \\
\text { Utara }\end{array}$ & $\begin{array}{l}0.002832-0.676146-0.077752 \text { PAD }+1.088875 \text { BD }+ \\
0.006991 \text { PDRB }+\mu_{\text {it }} \\
-0.673314-0.077752 \text { PAD }+1.088875 \text { BD }+0.006991 \\
\text { PDRB }+\mu_{\text {it }}\end{array}$ \\
\hline FSPalu & $\begin{array}{l}-0.061838-0.676146-0.077752 \text { PAD }+1.088875 \text { BD }+ \\
0.006991 \text { PDRB }+\mu_{\text {it }} \\
-0737984-0.077752 \text { PAD }+1.088875 \text { BD }+0.006991 \\
\text { PDRB }+\mu_{\text {it }}\end{array}$ \\
\hline
\end{tabular}

The results of the random effects model in the 13 districts/cities above illustrate the effect of PAD, BD and GRDP on Fiscal Stress. The equation above shows that the regression model for each district/city has a different intercept and the same slope. The difference intercept indicates that there are differences in the conditions of each cross section both at one time and at other times. The condition in question is the existence of different endogenous factors in the form of geographical conditions and natural resources in supporting local-own source revenue.

\section{B. Goodness of Fit $\left(\mathbf{R}^{2}\right)$}

This test is used to see how much variation in the dependent variable can be explained by the independent variable, to see the results in the determination test on panel data, the Adjusted R-squared value is used. The regression results in this study the Adjusted R-squared value is 0.98 , meaning that 98 percent of Fiscal Stress is influenced by PAD, BD and GRDP, while 2 percent is influenced by the other variables not described in this study. 


\section{Hypothesis test \\ 1. F-Statistics Test}

This test is used to determine whether the independent variable has a significant effect on the dependent variable simultaneously. The results of this test can be seen in the table below:

Table 2

F-Statistic Test

\begin{tabular}{lr}
\hline F-Statistic & Probability (F-statistic) \\
\hline 1772.019 & 0.000000 \\
\hline
\end{tabular}

Source: Attachment 10

The results of the $\mathrm{F}$ test analysis show that the PAD, BD and PDRB variables simultaneously have a significant effect on the Fiscal Stress variable (probability $<5$ percent), it is the F-Statistic probability number is $0.00000<0.05$. So that the null hypothesis in this study is rejected, namely PAD, BD and GRDP simultaneously have no significant effect on Fiscal Stress in the District/Province of Central Sulawesi in period 2014-2018.

\section{2. t-Statistic Test}

The t-statistics test is used to determine whether each variable independent has an influence on the dependent variable. The results of this test can be seen in the table below:

Table 3

T-statistics test results

\begin{tabular}{lrrrr}
\hline $\begin{array}{l}\text { Variab } \\
\text { le }\end{array}$ & coefficient & Error Standard & t-Statistics & Probablity \\
\hline C & -0.676146 & 0.311947 & -2.167502 & 0.0341 \\
PAD & -0.077752 & 0.011579 & -6.715044 & 0.0000 \\
BD & 1.088875 & 0.020509 & 53.09303 & 0.0000 \\
PDRB & 0.006991 & 0.014904 & 0.469071 & 0.6407 \\
\hline
\end{tabular}

Source: Attachment 10

The above table shows the effect of each independent variable on the dependent variable. An explanation of the relationship between these variables is as follows:

a. t-statistics test Local-own Resource Revenue (PAD)

Partially (t-test), PAD variable has a probability of 0.0000 when compared with the significant level of 5 percent (probability $<5$ percent), meaning that PAD has a negative and significant effect on the Fiscal Stress variable, so the null hypothesis in this study is rejected, it can be said PAD partially has no significant effect on Fiscal Stress in districts/province of Central Sulawesi period 2014-2018.

b. t-statistic test Regional Expenditure (BD)

Partially ( $t$ test), the BD variable has a probability of 0.0000 when compared to the significant level of 5 percent (probability $<5$ percent), meaning that BD has a 


\section{DETERMINANTS OF FISCAL STRESS \\ IN CENTRAL SULAWESI 2014-2018 PERIOD}

positive and significant impact on the Fiscal Stress variable, so the null hypothesis in this study is rejected, namely BD partially has a positive and significant effect on Fiscal Stress in the districts/cities of Central Sulawesi Province for the 2014-2018 period.

c. t-statistic test Gross Regional Domestic Product (PDRB)

Partially ( $t$ test) PDRB variable has a probability value of 0.6407 which when compared to the significant level of 5 percent (probability $>5$ percent), meaning that PDRB variable has a positive and insignificant effect on Fiscal Stress, so the null hypothesis in this study can not be rejected, which is PDRB partially does not have a significant effect on Fiscal Stress in the districts/cities of Central Sulawesi Province period 2014-2018.

\section{Classical Assumption Test}

This study uses a random effect model. The random effect model is a model that uses the Generalized Least Squares (GLS) approach. GLS is a method that uses information to be calculated explicitly which is able to produce an estimator that is Best Linear Unbiased Estimator (BLUE). GLS is an Ordinary Least Squares (OLS) model whose variables are transformed to meet the standard assumptions on the least squares (Gujarati, 2004). The GLS approach is also better and more efficient than the OLS approach (Greene, 2002). Based on the above explanation, this study did not test the classical assumption, because this study used a random effects model that met the BLUE requirements.

Regional autonomy is a policy implemented by the Central Government to support equitable development between regions in Indonesia. This policy gives full authority to Regional Governments to regulate fiscal and development in their respective regions. Regional revenues consist of transfer funds and local-own source revenue (PAD), if most local government revenues derive from transfer funds, it will cause fiscal pressure (Fiscal Stress). Fiscal Stress conditions indicate the inability of the region to meet the needs of BD come from within the region itself in the form of PAD.

The statistical results above using a random effect model approach show that simultaneously the PAD, BD and GRDP variables have a significant effect on Fiscal Stress. Partially, only PAD and BD variables have a significant effect on Fiscal Stress. While PDRB variable does not have a significant effect on Fiscal Stress.

\section{A. The Effect of Local-owned Resource Revenue on Fiscal Stress}

This study shows that the PAD variable has decreasing effect significantly on Fiscal Stress in the Districts/cities of Central Sulawesi Province. When PAD increases, Fiscal Stress decreases significantly, it means when the contribution of $\mathrm{PAD}$ is greater than $\mathrm{BD}$, the dependence on transfer funds from the Central Government will decrease and the regions will be able to increase the independence so that Fiscal Stress will decrease.

The results of this study are in line with research by Muda (2012) and Septira and Prawira (2019) that PAD has an influence on Fiscal Stress and the opposite of the results of research by Adriana et al. (2017) and Dwitayanti et al. (2019) which explains that PAD has no effect on Fiscal Stress. The greater the income that comes from PAD, not from transfer funds, so that the regions are more flexible in allocating budgets for regional interests without any element of interest from the Central Government that does not match with regional needs (Muda, 2012). The impact of 
PAD that can reduce Fiscal Stress will provide opportunities for local governments to pay more attention to PAD management (Septira and Prawira, 2019).

Increasing PAD in a region shows the region can optimize every potency as well as fiscal capacity to optimize sources of revenue comes from the region itself. If the increase in PAD occurs continuously, then generally the Fiscal Stress situation can decrease because Fiscal Stress shows the region that still not be able to optimize the sources of local revenue. Fiscal Stress in a region will encourage and motivate local governments to reduce dependence on the central government through increasing PAD.

\section{B. The Effect of Regional Expenditure on Fiscal Stress}

Different results were found in the BD variable, BD has an increasing and significant effect on Fiscal Stress in the districts / cities of Central Sulawesi Province. The increase in Fiscal Stress is due to the large proportion of BD derives from transfer funds, so that an increase in $\mathrm{BD}$ will have an impact on increasing regional fiscal dependence and Fiscal Stress is getting bigger.

The test result of BD variable is ifferent from the result of previous studies, due to the use of different spending variables in influencing Fiscal Stress. The different results in the BD variable in this study, because the expenditure variable comes from government spending as a whole, not only on the capital/development expenditure side. The use of the BD variable is based on the fact that the fiscal allocation is not only for the capital/development expenditure side, but also for the operational side and most of the portion of government expenditure is spent on operational expenditure or non-development expenditure.

BD has a very important role in Fiscal Stress, which BD can increase Fiscal Stress. The higher the BD, the higher the Fiscal Stress. The increase in Fiscal Stress is caused by BD which increases continuesly, but it is not compensated by increasing on PAD and tends to depend on transfer funds, so that it will impact on increasing Fiscal Stress. High Fiscal Stress illustrates the ability of local governments to adjust their budgets for BD. If BD is not adjusted to the ability of the region to finance the expenditures, it will increase Fiscal Stress along with the development of BD.

\section{Effect of Gross Regional Domestic Product on Fiscal Stress}

The result obtained on the PDRB variable shows an increasing and insignificant effect on Fiscal Stress in the districts / cities of Central Sulawesi Province. The results of this study are in line with the results of previous studies conducted by Muda (2012) and Adriana et al. (2019) which found that PDRB had no significant effect on Fiscal Stress. These results indicate that PDRB has no effect on Fiscal Stress. This situation is because PDRB does not directly affect Fiscal Stress in Central Sulawesi Province in period 2014 to 2018, but PDRB affects PAD through regional taxes and regional retribution caused by increased economic activity in a region which will later affect Fiscal Stress.

\section{CONCLUSION}

Simultaneously, the variables of PAD, BD and GRDP have a significant effect on Fiscal Stress in the districts /cities of Central Sulawesi Province period 2014-2018. Partially, the PAD variable has a negative and significant effect on Fiscal Stress in the districts / cities of Central Sulawesi Province period 2014-2018. BD variable has a positive and significant effect on Fiscal Stress in the districts /cities of Central Sulawesi Province period 2014-2018. While PDRB variable has a positive 


\section{DETERMINANTS OF FISCAL STRESS \\ IN CENTRAL SULAWESI 2014-2018 PERIOD}

and insignificant effect on Fiscal Stress in the districts /cities of Central Sulawesi Province for period 2014-2018.

\section{References}

Adriana, M., Basri, Y. M., dan Indrawati, N. (2017). Variabel Yang Mempengaruhi Fiscal Stress di Kabupaten/Kota Se-Provinsi Riau. Variabel Yang Mempengaruhi Fiscal Stress Di Kabupaten/Kota Se-Provinsi Riau. Jurnal Ekonomi, 25(2), 45-60.

https://je.ejournal.unri.ac.id/index.php/JE/article/viewFile/6042/5560.

Arnett, S. (2011). Fiscal Stress in the U.S. States : an Analysis of Measures and Responses.

https://smartech.gatech.edu/xmlui/bitstream/handle/1853/42860/arnett_sara h_b_201112_phd.pdf? sequence $=1$.

Badan Pusat Statistik Provinsi Sulawesi Tengah. (2015). Provinsi Sulawesi Tengah Dalam Angka 2015. https://sulteng.bps.go.id/publication/download.html?

Badan Pusat Statistik Provinsi Sulawesi Tengah. (2016). Provinsi Sulawesi Tengah dalam Angka 2016. https://sulteng.bps.go.id/publication/download.html?

Badan Pusat Statistik Provinsi Sulawesi Tengah. (2017). Provinsi Sulawesi Tengah Dalam Angka 2017. https://sulteng.bps.go.id/publication/download.html?

Badan Pusat Statistik Provinsi Sulawesi Tengah. (2018). Provinsi Sulawesi Tengah Dalam Angka 2018. https://sulteng.bps.go.id/publication/download.html?

Badan Pusat Statistik Provinsi Sulawesi Tengah. (2019). Provinsi Sulawesi Tengah dalam Angka 2019.

https://sulteng.bps.go.id/publication/download.html?.

Cornia, Gary. (2004). "Fiscal Planning, Budgeting, and Rebudgeting Using Revenue Semaphores". Public Administration Review 64(2): 164-179.

Dwitayanti, Y., Nurhasanah, dan Armaini, R. (2019). Determinan Fiscal Stress Pemerintah Daerah Di Provinsi Sumatera Selatan. Determinan Fiscal Stress Pemerintah Daerah di Provinsi Sumatera Selatan. Jurnal Riset Terapan Akuntansi, 03, 68-78.

https://www.jurnal.polsri.ac.id/index.php/jrtap/article/viewFile/1420/837.

Ekananda, M. (2016). Analisis Ekonometrika Data Panel. Mitra Wacana Media. Jakarta.

Forrester, John. (2002). The Principal-Agent Model and Budget Theory. In Khan, Aman dan W. Barthley Hildreth. 2002. Budget Theory in the Public Sector. Westport, Connecticut: Quorum Books. Hagen.

Ghozali, I. (2013). Aplikasi Analisis Multivariat dengan Program IBM SPSS. Edisi 7. Universitas Diponegoro. Semarang.

Greene, W. H. (2002). Econometric Analysis. Prentice Hall. New Jersey.

Gujarati, D. N. (2004). Basic Econometrics 4th Edition. The McGraw-Hill. New York. 


\section{AFEBI Economic and Finance Review (AEFR) \\ Volume 5, No 02 (2020)}

Gujarati, D. N., dan Porter, D. C. (2009). Basic Econometrics 5th Edition. The McGraw -Hill. New York.

Gujarati, D. N. (2012). Dasar-Dasar Ekonometrika: Terjemahan Mangunsong, $R, C$. Salemba Empat: Buku 2. Edisi 5. Jakarta.

Hakim, A. R., dan Subandi, S. (2014). Ekonometri. Graha Ilmu. Yogyakarta.

Halim, A., dan Mada, U. G. (2001). Anggaran Daerah Dan "Fiscal Stress" (Sebuah Studi Kasus pada Anggaran Daerah Provinsi di Indonesia). Journal of Indonesian Economy and Business, 16(4), 346-357. https://journal.ugm.ac.id/jieb/article/download/39812/22460.

Junita, A., dan Abdullah, S. (2016). Pengaruh Fiscal Stress Dan Legislature Size Terhadap Expenditure Change Pada Kabupaten/Kota di Sumatera Utara. Jurnal Akuntansi, 20(3), 467-478. https://doi.org/10.24912/ja.v20i3.10.

Kurniawan, A., dan Arza, F. I. (2019). Pengaruh Fiscal Stress, Varians Anggaran dan Perubahan Sisa Lebih Perhitungan Anggaran Terhadap Perubahan Anggaran Belanja Pada Pemerintah Daerah. Jurnal Eksplorasi Akuntansi, 1(3), 12751292.

http://jea.ppj.unp.ac.id/index.php/jea/article/download/142/102.

Lhutfi, I., Ritchi, H., dan Yudianto, I. (2019). Bagaimana Pemerintah daerah merespon Fiscal Stress? Jurnal Ilmiah Ekonomi Global Masa Kini, 10(02), $76-81$. http://ejournal.uigm.ac.id/index.php/EGMK/article/viewFile/840/982.

Manafe, M. W. N., Ena, Z., dan Adu, S. S. (2018). Fiscal Stress: Studi Kasus Pemda Provinsi Nusa Tenggara Timur. Wahana, 21(2), 125-135. https://doi.org/10.35591/whn.v21i2.152.

Muda, I. (2012). Variabel Yang Mempengaruhi Fiscal Stress Pada Kabupaten/Kota Sumatera Utara. Jurnal Keuangan dan Bisnis, 4(1).

Https:/Www.Researchgate.Net/Profile/Iskandar_Muda4/Publication/27216 5017_Variabel_Yang_Mempengaruhi_Fiscal_Stress_Pada_Kabupatenkota_ Sumatera_Utara/Links/54dcbe1f0cf282895a3b1cd0/Variabel-YangMempengaruhi-Fiscal-Stress-Pada-Kabupaten-Kota-Sumatera-Utara.Pdf.

Muryawan, S. M., dan Sukarsa, M. (2016). Kinerja Keuangan Daerah Terhadap Pertumbuhan Ekonomi Di Kabupaten/Kota Provinsi Bali. E-Jurnal Ekonomi Dan Bisnis Universitas Udayana, 2, 229-252.

Https://Ojs.Unud.Ac.Id/Index.Php/EEB/Article/Download/9379/12798.

Pemerintah Indonesia. (1999). Undang-Undang Nomor 25 Tahun 1999 Tentang Perimbangan Keuangan Antara Pemerintah Pusat Dan Daerah. http://www.dpr.go.id/dokjdih/document/uu/UU_1999_25.pdf .

Pemerintah Indonesia. (2004). Undang-Undang Nomor 32 Tahun 2004 Tentang Pemerintah Daerah. http://www.dpr.go.id/dokjdih/document/uu/33.pdf.

Pemerintah Indonesia. (2004). Undang-Undang Nomor 33 Tahun 2004 Tentang Pemerintah Daerah. http://eprints.uanl.mx/5481/1/1020149995.PDF.

Pemerintah Indonesia. (2006). Peraturan Menteri Dalam Negeri Nomor 13 Tahun 2006 Tentang Pedoman Pengelolaan Keuangan Daerah. https://sipkddki.jakarta.go.id/files/permendagri_13_2006.pdf.

Pemerintah Indonesia. (2011). Peraturan Pemerintah Nomor 21 Tahun 2011 


\section{DETERMINANTS OF FISCAL STRESS \\ IN CENTRAL SULAWESI 2014-2018 PERIOD}

Tentang pedoman Pengelolaan Keuangan Daerah.

https://jdih.surabaya.go.id/pdfdoc/permendagri_58.pdf.

Pemerintah Indonesia. (2015). Undang-Undang Nomor 9 Tahun 2015 Tentang Pemerintah Daerah. https://www.bphn.go.id/data/documents/15uu009.pdf.

Pemerintah Indonesia. (2018). Peraturan Pemerintah Nomor 2 Tahun 2018 Tentang Standar Pelayanan Minimal.

https://peraturan.bpk.go.id/Home/Details/67029/pp-no-2-tahun-2018.

Pemerintah Indonesia. (2019). Peraturan Pemerintah Nomor 12 Tahun 2019 Tentang Pengelolaan Keuangan Daerah.

https://peraturan.bpk.go.id/Home/Download/94590/PP Nomor 12 Tahun 2019.pdf.

Pemerintah Indonesia. (2019). Peraturan Menteri Dalam Negeri Nomor 90 Tahun 2019 Tentang Klasifikasi, Kodefikasi dan Nomenklatur Perencanaan Pembangunan dan Keuangan Daerah. https://doi.org/10.16194/j.cnki.311059/g4.2011.07.016.

Pemerintah Indonesia. (2020). Keputusan Menteri Dalam Nageri (Kepmendagri) Nomor 050-3708 Tahun 2020 tentang Hasil Verifikasi dan Validasi Pemutakhiran Klasifikasi, Kodefikasi dan Nomenklatur Perencanaan Pembangunan dan Keuangan Daerah.

http://bappeda.bengkuluselatankab.go.id/wp-

content/uploads/2020/10/Kepmendagri-050-3708-Tahun-2020-

Pemutakhiran.pdf.

Reschovsky, A. (2003). The Implication of State Fiscal Stress for Local Governments. Urban Institute Conference, State Fiscal Crises: Causes, Consequences, and Solutions., 53706 (April).

http://taxpolicycenter.org/UploadedPDF/1000612.pdf.

Septira, F., dan Prawira, I. F. A. (2019). Analisis Faktor-Faktor Yang Mempengaruhi Fiscal Stress. Jurnal Pendidikan Akuntansi dan Keuangan, 7(1), 57. https://doi.org/10.17509/jpak.v7i1.15949.

Setiyawan, Budi dan Adi, Priyohari. (2006). Pengaruh Fiscal Stress terhadap Pertumbuhan Pendapatan Asli dan Belanja Daerah (Studi Empiris pada Kabupaten/Kota se-Jawa Tengah. Simposium Nasional Akuntansi $X$. Makassar.

Shamsub, H dan Akoto, J, B. 2004. State and Local Fiscal Structures and Fiscal Stress. Journal of Public Budgeting, Accounting dan Financial Management, 16(1), 40-61.

Sugiyono. (2017). Metode Penelitian Kuantitatif, Kualitatif dan R dan D. Alfabeta. Bandung.

Usman, H., dan Nachrowi, N. D. (2005). Penggunaan Teknik Ekonometrika. Raja Grafindo Persada. Jakarta.

Widarjono, A. (2009). Ekonometrika Pengantar dan Aplikasinya. Edisi Ketiga. Ekonisia.Yogyakarta. 